\title{
Antique Dowry Chests In Private Homes
}

\author{
Maria Działo \\ Jagiellonian University in Kraków/ Institute of Ethnology and Cultural Anthropology
}

\begin{abstract}
Dowry chests are one of the most popular items of folk furniture, which according to popular opinion can only be seen in museums. This is a false belief, because these items are found in large numbers in Poland, especially in its eastern, agricultural area s. The main source of this paper is field research, which I conducted in eastern Poland during which 205 chests and trunks were found, only in private homes. The furniture found in this area is represented by tall, mobile boxes mounted on wheels, painted by floral decoration, produced in the 19th and first half of the twentieth century. Originally, dowry chests were used to store the dowry of the bride, currently it is completely different. The chests have been converted by their owners for commercial use _ such as a meat smokehouse, container for cattle'f food or other items. The paper discusses the semiotics of this chests in the past and in the presence, their adaptation to the new function, as well as changes and tendencies in contemporary culture.
\end{abstract}

Keywords: artifacts; adaptation; bride; folk furniture; Poland 